\title{
Signifikansi Salib Bagi Kehidupan Manusia dalam Teologi Paulus
}

\author{
David Eko Setiawan, Dwiati Yulianingsih ${ }^{1)^{*}}$ \\ 1) Sekolah Tinggi Teologi Tawangmangu \\ ${ }^{*}$ Penulis Korspondensi: davidekosetiawan14217@gmail.com
}

Diterima:15 Okt 2019 / Direvisi: 20 Nov. 2019 / Disetujui: 03 Des. 2019

\begin{abstract}
Abstrak
Rasul Paulus adalah salah satu teolog besar dalam Perjanjian Baru yang kaya dengan pemikiran teologis. Salah satu hasil pemikirannya adalah tentang signifikansi salib bagi kehidupan manusia. Penulis memandang penelitian ini penting, karena akan semakin memperjelas hal tersebut.

Rumusan Masalah di dalam penelitian ini adalah bagaimanakah signifikansi salib bagi manusia dalam teologi Paulus? Adapun Tujuan penelitian ini adalah untuk menjelaskan signifikansi salib bagi manusia dalam teologi Paulus. Sedangkan metode yang dipakai oleh penulis adalah menggunakan literature reasech. Hasil dari penelitian menunjukkan bahwa dalam teologi Paulus, salib memiliki signifikansi yang besar bagi kehidupan manusia, karena salib adalah kekuatan Allah yang menyelamatkan umat manusia, tempat pertukaran penghukuman, jaminan kebebasan dari kutuk, dan tempat pendamaian.
\end{abstract}

Kata Kunci: Signifikansi, Salib, Teologi Paulus

\section{Abstrack}

The Apostle Paul is one of the great theologians in the New Testament who are rich in theological thought. One result of his thinking is about the significance of the cross for human life. The authors view this research as important, because it will further clarifies this matter.

The problem formulation in this study is what is the significance of the cross for humans in Paul's theology? The purpose of this study is to explain the significance of the cross to humans in Paul's theology. While the method used by the author is to use the literature research. The results of the study show that in Paul's theology the cross has great significance for human life, 
because the cross is the power of God that saves mankind, a place of exchange of punishment, guaranteed freedom from curses, and a place of reconciliation.

Keywords: Significance, the Cross, Paul's Theology

\section{Pendahuluan}

Rasul Paulus adalah salah satu penulis Perjanjian Baru yang sangat tertarik dengan tema Salib. Moriss menjelaskan pernyataan di atas sebagai berikut, "Bagi Paulus makna salib itu begitu besar, sehingga banyak masalah dapat diselesaikan oleh salib." ${ }^{1}$ Salah satu contoh ketika terjadi friksi di Jemaat Korintus, Paulus menghadapkan semua friksi dengan pusat ajaranya yaitu salib Kristus (1 Korintus 1:12-19). ${ }^{2}$ Salib bukan sekedar tema biasa dalam surat-surat Paulus, namun di dalamnya terdapat makna yang begitu luas dan dalam sehingga menarik untuk dibahas.

Sebelum membahas hal tersebut lebih jauh, perlu ditegaskan bahwa pada dasarnya tema salib dalam teologi Paulus bukanlah tema yang diskontinu (baca: tidak bersinambung) dengan ajaran Yesus dan rasul-rasul lain. ${ }^{3}$ Hal ini perlu ditegaskan sebab ada tuduhan yang mengatakan bahwa Pauluslah yang menjadikan kematian Yesus melalui penyaliban sebagai kematian yang menggantikan umat tebusan-Nya (the substitutionary death of Christ) serta kebangkitan-Nya sebagai pilar utama dalam Soteriologi Kristen. ${ }^{4}$ Ajaran tersebut hanya diajarkan Paulus namun tidak diajarkan oleh Yesus dan rasul-rasul yang lain. Tuduhan tersebut dibantah oleh Nggadas dengan menggunakan argumentasi kerygma, ${ }^{5}$ sebagai berikut,

"Mengapa kerygma itu penting? Karena, telah menjadi konsensus di kalangan para pakar Yesus Sejarah maupun pakar teologi Paulus bahwa di dalam Surat-surat Paulus yang merupakan dokumendokumen terawal PB, terdapat kutipan-kutipan dari formulaformula pengakuan iman maupun ringkasan pengajaran Gereja

${ }^{1}$ Leon Moris, Teologi Perjanjian Baru (Malang: Penerbit Gandum Mas, 1996), 88

2 Moris, 88.

${ }^{3}$ Tuduhan ini dimunculkan oleh Louay Fatoohy, The Mystery of the Crucifixion: The Attempt to Kill Jesus in the Qur'an, New Testament and Historical Sources (Birmingham: Luna Plena Publishing, 2008), 59

${ }^{4}$ Fatoohy, 59

${ }^{5}$ Menurut para sarjana Alkitab, istilah Kerygma mengacu pada inti dari tradisi lisan gereja mula-mula tentang Yesus. 
mula-mula yang disebut kerygma. Dan kerygmata (jamak) tersebut, dari segi kronologisnya, mendahului eksistensi Surat-surat Paulus. Bukan Paulus yang mengkomposisi atau menciptakan kerygmata tersebut". 6

Berdasarkan penjelasan Nggadas di atas tampak bahwa tulisan-tulisan Paulus pada dasarnya merupakan kelanjutan dari ajaran gereja mula-mula yang notabene adalah ajaran Yesus dan juga para rasul lainnya. Sehingga dapat dikatakan bahwa teologi Paulus tidak berdiri sendiri, namun merupakan kelanjutan dari teologi Yesus. ${ }^{7}$ Bagaimanakah rasul Paulus memaknai salib di dalam teologinya? Hal inilah yang akan diangkat penulisuntuk menjelaskan kepada pembaca agar lebih mengenal signifikansi salib di dalam teologi Paulus.

\section{Metode Penelitian}

Metode penelitian yang digunakan di dalam penelitian ini adalah menggunakan metode studi pustaka. Zed mendefinisikan metode studi pustaka sebagai serangkaian kegiatan yang berkenaan dengan metode pengumpulan data pustaka, membaca dan mencatat serta mengolah bahan penelitian. ${ }^{8}$ Peneliti berusaha menghimpun informasi yang relevan dengan topik atau masalah yang menjadi obyek penelitian melalui jurnal dan bukubuku. Beberapa sumber pustaka yang digunakan oleh peneliti adalah bukubuku karya Paul Enn, J. Echkard Schnabel, Leon Moris, Donald Gutrie, L. Darell Bock, Roland Allen, Jhon Drane. Selain itu peneliti juga menggunakan beberapa jurnal ilmiah karangan Daniel Ronda, David Eko Setiawan dan Heriyanto.

${ }^{6}$ Deky Hidnas Yan Nggadas dalam Tinjauan kritis terhadap buku Louay Fatoohy, "The Mystery of the Crucifixion", www.academia.edu, diakses tgl. 15 Februari 2019. Anggapan tentang pentingnya Kerygma oleh Nggdas didasarkan pada temuan adanya formula-formula pengakuan iman gereja mula-mula yang dikutip dalam surat-surat Paulus oleh para pakar Yesus Sejarah dan Teologi Paulus yang menunjukkan bukti adanya kontinuitas pengajaran gereja mula-mula dengan pengajaran Paulus.

${ }^{7}$ Dalam ungkapan yang lain, Kapojos menjelaskan bahwa inti pemberitaan Paulus adalah mengenai setiap ajaran Yesus Kristus. Lih. Shintia Maria Kapojos dan Hengki Wijaya, "Konsep Bermegah (Boasting) dalam Surat Roma dan Implikasinya bagi Gereja Masa Kini”, Fidei: Jurnal Teologi Sistematika dan Praktika, Vol. 2, No. 1, 2019, 8-9

${ }^{8}$ Mestika Zed, Metode Penelitian Kepustakaan (Jakarta: Yayasan Obor Indonesia, 2008), 3. 
Selanjutnya data yang diperoleh dari berbagai sumber di atas dianalisis dengan menggunakan metode Thematic analysis. Metode analisis tersebut merupakan salah satu cara untuk menganalisa data dengan tujuan untuk mengidenifikasi pola atau untuk menemukan tema melalui melalui data yang telah dikumpulkan oleh peneliti. ${ }^{9}$ Proses analisis dilakukan dengan cara mencermati keterkaitan, kesamaan, dan kesesuaian dengan tema. ${ }^{10}$ Hasil analisis tersebut kemudian diuraikan secara deskriptif dan sistematis sesuai dengan konsep penulis. ${ }^{11}$

\section{Pembahasan}

Teologi Paulus tidak dapat dipisahkan dari pengalaman hidupnya. ${ }^{12}$ Berangkat dari pengalamannya, Paulus telah merumuskan teologinya, dan selanjutnya teologi Paulus menafsirkan pengalaman masa lalunya serta membentuk pengalaman yang akan ia jalani. ${ }^{13}$ Bagi Paulus, teologi dan pengalaman religiusnya tidak dapat dipisahkan. ${ }^{14}$ Berdasarkan hal tersebut, maka pertama-tama penulis menyajikan latar belakang kehidupan Paulus. Hal ini dilakukan agar didapatkan perspekif yang utuh antara pengalaman religius Paulus dengan teologinya, khususnya pandangan teologinya terhadap signifikansi salib bagi kehidupan manusia.

\section{Biografi Paulus}

Paulus adalah salah satu rasul Kristus yang kehidupannya menarik untuk dipelajari. Pribadi dan karya-karyanya telah menginspirasi dunia pelayanan Kristen. Bagaimana latar belakang kehidupan dan pelayanan Paulus? Dan apa sajakah karya-karyanya yang begitu menginspirasi gereja

${ }^{9}$ Heriyanto, "Thematic Analysis sebagai Metode Menganalisa Data untuk Penelitian Kualitatif', ANUVA: Jurnal Kajian Budaya, Perpustakaan dan Informasi, Vol. 2, No. 3, 318

10 Daniel Ronda, "Kepemimpinan Kristen Di Era Disrupsi Teknologi." Evangelikal: Jurnal Teologi Injili dan Pembinaan Warga Jemaat, Vol. 3, No. 2, 2019, 1-8.

${ }^{11}$ Ronda, 1-8

12 J. Knox Chamblin, Paulus dan Diri: Ajaran Rasuli bagi Kutuhan Pribadi, (Surabaya: PN Momentum, 2006), 1

${ }^{13}$ Chamblin, 2 1974), 377

${ }^{14}$ George E. Ladd, A Theology of The New Testament (Grand Rapids: Eerdmans, 
Tuhan? Berikut ini dipaparkan latar belakang kehidupan dan pelayanan Paulus beserta karya-karyanya.

\section{Asal Usul Paulus}

Paulus lahir sebagai seorang Yahudi, seperti terlihat dari namanya, 'Saulus' (lih. Kisah 7:58; 8:1,3, dll). ${ }^{15}$ Dia memiliki nama Ibrani Saul (Ibrani: Sa'ul; Yunani: Saulos) dan nama Romawinya adalah Paulos. ${ }^{16}$ Pate menjelaskan hal tersebut sebagai berikut,

Kisah Para Rasul 13:9 berkata bahwa Saulus pada saat yang sama disebut Paulus, dengan demikian menghilangkan kesalahapahaman umum bahwa nama sang rasul diubah dari Saulus ke Paulus pada saat pertobatannya. Pada zaman dahulu wajarlah bila orang-orang Yahudi memiliki baik nama Semitik maupun Romawi". ${ }^{17}$

Paulus dilahirkan di Tarsus di Asia Kecil, sebuah kota yang terkemuka di zaman itu, di wilayah Kilikia (Kisah 21:39; 22:3) sekitar tahun 10 M. ${ }^{18}$ Dia memiliki dwi kewarganegaraan, yaitu warga negara Romawi dan Yahudi. Marsunu menjelaskan asal usul dwi kewarganegaraan Paulus sebagai berikut: "Orang tua Paulus adalah seorang Yahudi perantauan. Dari orang tuanya Paulus mewarisi kewarganegaraan Roma". ${ }^{19}$ Selanjutnya Schnabel menjelaskan hubungan dwi kewarganegaraan Paulus yang diperoleh dari ayahnya sebagai berikut,

"Nama Paulos atau 'Paul' bisa jadi merupakan cognomen keluarganya, yaitu unsur resmi namanya sebagai warga negara Romawi, yang diterima keluarganya setelah manumisi dari majikan Romawi, yang diterima Romawi yang membebaskan nenek moyangnya (ayahnya) dari perbudakan. Perlu diketetahui, manumisi adalah pendewasaan anak yang masih di bawah umur dengan ketetapan pengadilan. Atau 'Paulus'merupakan signum atau

${ }^{15}$ C. Marvin Pate, Teologi Paulus (Malang: PN. Gandum Mas, 2004), 18.

${ }^{16}$ Eckhard J. Schnabel, Rasul Paulus Sang Misionaris: Perjalanan, Startegi, dan Metode Misi Rasul Paulus (Yogyakarta: Yayasan Andi, 2008). 26

${ }^{17}$ Pate, 18

18 YM Seto Marsunu, Paulus Sukacita Rasul Kristus (Yogyakarta: Penerbit Kanisius, 2012). 14

${ }^{19}$ Marsunu, 14 
supernomen, yaitu nama Yahudi yang di-Latin-kan yang digunakan sebagai nama Romawi oleh keluarga itu". ${ }^{20}$

Selanjutnya Saulus atau Paulus muda meninggalkan Tarsus dan berpindah ke Yerusalem. Tidak diketahui secara pasti kapan Paulus berpindah. Beberapa ahli berpendapat bahwa perpindahan itu mungkin terjadi ketika ia masih kecil, yang bisa berarti ia melewati masa-masa pertumbuhan di Yerusalem. Kemudian dia mulai belajar di bawah bimbingan Rabi Gamaliel dan menerima pendidikan retorika dasar (Yunani) di sekolah Yahudi-Helenistik di Yerusalem. ${ }^{21}$ Dari Rabi Gamaliel inilah akhirnya Paulus mewarisi pemikiran aliran kaum Farisi (Kisah 26:5; Filipi 3:4-6). ${ }^{22}$ Pate menjelaskan latar belakang pendidikan teologi Paulus sebagai berikut,

"Pendidikan teologi Paulus adalah pendidikan seorang Farisisebuah kelompok orang Yahudi ortodoks pada abad pertama (Filipi 3:5-6; lih. juga Kisah 23:6; 26:5). Dia belajar di bawah salah seorang guru Farisi yang paling terkemuka pada periode tersebut, yaitu Gamaliel, Sang Penatua (Kisah 22:3), yang adalah anggota Sanhedrin badan keagamaan yang berkuasa dalam Yudaisme (Kisah 5:34)". ${ }^{23}$

Selanjutnya Paulus muda menjelma menjadi seorang Farisi menurut Mahzab yang paling keras dalam agama Yahudi. Sebagai orang Farisi, dia dengan tegas dan keras mempertahankan nilai-nilai rohani dan keagamaan yang tinggi. ${ }^{24}$ Dia amat bersungguh-sungguh dalam usahanya untuk menaati Hukum-hukum Perjanjian Lama yang tertulis sebanyak 613 perintah dan tradisi-tradisi ahli Taurat yang lisan sebanyak 6000. ${ }^{25}$ Memang, sangat mungkin Paulus akan mendapat giliran menjadi guru Hukum Taurat yang terkemuka dari generasinya. ${ }^{26}$

\footnotetext{
${ }^{20}$ Schnabel, 27.

${ }^{21}$ Schnabel, 29

${ }^{22}$ Marsunu, 15-16

${ }^{23}$ Pate, 21.

${ }^{24}$ Marsunu, 15-16

${ }^{25}$ Pate, 21

${ }^{26}$ Pate, 21
} 


\section{Paulus Si Penganiaya}

Paulus muda yang sangat fanatik dan religius ini kemudian menjadi sosok penganiaya jemaat. Dia menjadi penganiaya pengikut Yesus di Yerusalem (Kisah 8:3) dan tempat-tempat yang lain di seluruh Yudea (Galatia 1:22-23). Mengapa Paulus menganiaya jemaat? Pate berpendapat bahwa, "Paulus begitu mengabdi pada agama nenek moyangnya hingga secara pribadi dia merasa berkewajiban untuk menyingkirkan dari Yudaisme saingan imannya yang terbaru, yaitu kekristenan (Kisah 9:1; I Korintus 15:9-12)". 27 Jawaban lainnya yang melatarbelakangi mengapa Paulus menganiaya jemaat dijelaskan oleh Schnabel sebagai berikut,

"Jawaban yang masuk akal adalah pemahaman bahwa pemberitaan pengikut awal Yesus dipandang sangat tercela dan sesat sehingga Paulus yakin sikap agresif perlu dilakukan untuk menghentikan aktivitas mereka. Orang Yahudi yang menolak klaim orang Yahudi yang percaya Yesus sangat yakin bahwa iman kepada Yesus sebagai Mesias dan dampak kematian Yesus di kayu salib sebagai penebusan dosa merupakan serangan terhadap fondasi ketaatan pada Taurat sebagai dasar keselamatan Israel yang telah dinyatakan Yahweh kepada Musa". ${ }^{28}$

Bagi Paulus tidak mungkin Yesus itu Mesias karena beberapa alasan: pertama, Yesus telah mewartakan bahwa Allah memberikan keselamatan kepada orang-orang yang dianggap pendosa dan najis. Kedua, Yesus dianggap melanggar Hukum Taurat (bekerja pada hari Sabat, semua makanan halal), serta menyerang orang Farisi. Itulah yang membuat Paulus bereaksi keras terhadap para pengikut-Nya. ${ }^{29}$

\section{Pertobatan Paulus}

Pertobatan Paulus merupakan suatu peristiwa penting dalam kehidupanya dan merupakan tindakan langsung dari Allah yang memberikan dampak radikal baginya. ${ }^{30}$ Titik balik kehidupan Paulus Sang Penganiaya jemaat dimulai di jalan menuju Damsyik. Ketika dia sedang menempuh perjalanan dari Yerusalem ke Damsyik tiba-tiba ia mengalami




perjumpaan pribadi dengan Yesus. Perjumpaan itu dijelaskan Paulus sebagai melihat Tuhan (1 Korintus 9:1), sebagai penampakan Kristus yang telah bangkit (1 Korintus 15:8). Lukas menggambarkannya dalam bentuk cahaya yang memancar dari langit (Kisah 9:3; 22:6; 26:13). Peristiwa ini membuat Paulus jatuh ke tanah dan mendengar bahwa dia disapa oleh Yesus Tuhan. Lalu dia disuruh untuk pergi ke kota dalam keadaan tidak dapat melihat, tidak dapat makan dan minum selama tiga hari lamanya (Kisah 9:9).

Setelah kejadian yang luar biasa tersebut, Paulus dilayani oleh Ananias. Melalui pelayanannya, Paulus disembuhkan sehingga dapat melihat kembali. Kemudian Ananias berkata bahwa Tuhan Yesus telah mengutus Paulus untuk memberitakan firman ke seluruh dunia (Kisah 9:1516; 22:14-15). Penyingkapan Juru Selamat yang bangkit kepada Paulus memiliki efek yang amat kuat pada pusat pikirannya sehingga pengalaman tersebut menyadarkan dia bahwa Yesus yang disalibkan tidak lain adalah Mesias yang telah bangkit. ${ }^{31}$ Inilah yang mengubah hidupnya secara total.

\section{Paulus Sang Misionari}

Setelah pertobatannya, Paulus kemudia memulai pemberitaan injil. Schnabel membagi misi pemberitaan Injil oleh Paulus dalam lima belas periode yaitu; ${ }^{32}$ Periode pertama, misi pemberitaan Injil di wilayah Damsyik (Kisah 9:19-22; Galatia 1:1:17; Kisah 9:23-25). Periode kedua pemberitaan Injil di wilayah Arabia (Galatia. 1:15-17). Periode ketiga, pemberitaan Injil di Yerusalem (Galatia 1:18-19; Kisah 9:26-30). Periode keempat, pemberitaan Injil di Kilikia dan Siria (Galatia 1:21-24). Periode kelima, pemberitaan Injil di Anthiokia (Kisah 11:26). Periode keenam, pemberitaan Injil di Siprus (Kisah 13:4-12). Periode ketujuh, pemberitaan Injil di Galatia (Kisah 13:14-14:23). Periode kedelapan, pemberitaan Injil di provinsi Makedonia (Kisah 16:9-10). Periode kesembilan, pemberitaan Injil di provinsi Akhaya (Kisah 17:15-18: 14-16). Periode kesepuluh, pemberitaan Injil ke provinsi Asia (Kisah 19). Periode kesebelas, pemberitaan Injil di Ilirikum (Roma 15:19). Periode kedua belas, pemberitaan Injil ke Kaisarea (Kisah 21:14). Periode ketiga belas, pemberitaan Injil ke Roma (Kisah 27:1

\footnotetext{
${ }^{31}$ Pate, 22.

${ }^{32}$ Schnabel, 47-120
} 
- 28:16). Periode keempat belas, pemberitaan Injil ke Spanyol (Roma 15:2329). Periode kelima belas, pemberitaan Injil ke Kreta (Titus 1:5).

Paulus telah menjadi seorang misionaris Kristen yang berhasil sepanjang zaman. Pernyataan ini selaras dengan pendapat Drane berikut, "Mungkin Pauluslah misionari Kristen yang paling berhasil sepanjang zaman. Dalam kurun waktu kurang dari satu generasi, ia mengadakan perjalanan keseluruh wilayah dunia Laut Tengah, dan mendirikan jemaat-jemaat Kristen yang berkembang serta aktif kemana pun ia pergi". ${ }^{33}$

Kesuksesan Paulus di atas juga disoroti oleh Allen di dalam bukunya yang berjudul Missionary Method: St. Paul's or Ours? Allen menjelaskannya sebagai berikut:

"Dalam kurun waktu sepuluh tahun lebih sedikit, Paulus telah mendirikan gereja di empat provinsi Kekaisaran, yaitu Galatia, Makedonia, Akhaya dan Asia. Sebelum 47 M, tidak ada gereja di provisnsi ini; pada $57 \mathrm{M}$, Paulus bisa berbicara seolah-olah karyanya sudah selesai, dan bisa merencanakan perjalanan yang lebih jauh ke Barat tanpa khawatir bahwa gereja-gerejayang ia dirikan akan mati tanpa kehadirannya karena membutuhkan bimbingan dan dukungannya". ${ }^{34}$

Selain sukses mendirikan jemaat-jemaat lokal, Paulus juga telah berhasil melahirkan pemimpin-pemimpin jemaat lokal baru. ${ }^{35} \mathrm{Hal}$ itu merupakan komitmen Paulus untuk memelihara jemaat-jemaat baru yang telah didirikannya. ${ }^{36}$

\section{Paulus Seorang Teolog}

Paulus bukan sekadar sebagai pemberita injil yang sukses, namun dia juga seorang teolog handal telah menghasilkan karya-karya besar. Suratsurat kiriman yang ditulis untuk jemaat atau pribadi merupakan refleksi dari

\footnotetext{
${ }^{33}$ John Drane, Memahami Perjanjian baru (Jakarta: BPK Gunung Mulia, 2005), 344

${ }^{34}$ Roland Allen, Missionary Method: St. Pauls or Ours? Library of Historic Theology (London: Robert Scott Roxburghe 1912), 3

${ }^{35}$ David Eko Setiawan, Misi Perintisan Jemaat Alkitabiah-Kontekstual (Yogyakarta: Diandra, 2017), 45

${ }^{36}$ Derek J. Tidball, Teologi Pengembalaan, (Malang: Penerbit Gandum Mas, 1995), 113-114.
} 
pergumulan teologisnya. Ia menulis sebagai teolog yang membantu gerejagereja lokal untuk memahami Injil secara lebih lengkap dan konsisten. ${ }^{37}$ Bock menjelaskan lebih lanjut tentang sifat dari surat-surat Paulus sebagai berikut,

"Surat-surat Paulus merupakan teologi terapan, dan bahkan dalam bagian-bagiannya yang paling teoritis, sasarannya ia mendorong para pembacanya melihat dunia dan bagaimana mereka hidup di hadapan Allah dalam bidang-bidang dan perhatian yang spesifik dan nyata". ${ }^{38}$

Teologi Surat-surat Paulus ${ }^{39}$

\begin{tabular}{|c|c|c|c|c|}
\hline Ciri & Nama & Waktu & Asal & Teologi \\
\hline \multirow{6}{*}{ Umum } & Galatia & $48 \mathrm{M}$ & Antiokhia/Siri & \multirow{6}{*}{$\begin{array}{l}\text { Soteriologi } \\
\text { dan } \\
\text { Eskhatolog }\end{array}$} \\
\hline & 1 Tesalonika & $50 \mathrm{M}$ & Korintus & \\
\hline & 2 Tesalonika & $50 \mathrm{M}$ & Korintus & \\
\hline & 1 Korintus & $55 \mathrm{M}$ & Efesus & \\
\hline & 2 Korintus & $55 \mathrm{M}$ & Makedonia & \\
\hline & Roma & $57 \mathrm{M}$ & Korintus & \\
\hline \multirow{5}{*}{ Penjara } & Efesus & $62 \mathrm{M}$ & Roma & \multirow{4}{*}{ Kristologi } \\
\hline & Filipi & $63 \mathrm{M}$ & Roma & \\
\hline & Kolose & $62 \mathrm{M}$ & Roma & \\
\hline & Filemon & $62 \mathrm{M}$ & Roma & \\
\hline & 1 Timotius & $63 \mathrm{M}$ & Makedonia & \\
\hline
\end{tabular}

${ }^{37}$ Schnabel, 121.

${ }^{38}$ Darrell L. Bock, A Biblical Theology of The New Tastement (Malang: Penerbit Gandum Mas, 2011), 342

${ }^{39}$ Paul Enns, The Moody Hand Book Of Theology (Malang: Literatur SAAT,2004), 125 
Pastoral

\begin{tabular}{cccc}
\hline Titus & $63 \mathrm{M}$ & Korintus & EKklesiologi \\
\hline 2 Timotius & $67 \mathrm{M}$ & Roma & \\
& & & \\
\hline
\end{tabular}

Berdasarkan penjelasan di atas tampak bahwa surat-surat Paulus memiliki bobot teologi yang cukup dalam. Melalui surat-suratnya, jemaat dibimbing untuk memiliki pemahaman yang benar dan lengkap tentang Injil. Bahkan sering melalui surat-suratnya, dia menyelesaikan masalah-masalah praktis di dalam jemaat tanpa harus meninggalan pesan teologisnya.

\section{Signifikansi Salib Bagi Kehidupan Manusia Dalam Perspekstif Teologi Paulus}

Menurut Leon Moris, Paulus adalah satu-satunya penulis Perjanjian Baru yang menyebut soal salib secara berulang-ulang (I Korintus 1:17:18, Galatia 5:11; 6:12, 14, Efesus 2:16, Filipi 2:8; 3:18, Kolose 1:20, 2:14). ${ }^{40}$ Bahkan Pauluslah yang paling sering berbicara tentang peristiwa penyaliban (I Korintus 1:23; 2:2,8, II Korintus 13:4, Galatia 2:20) dan kematian Kristus. ${ }^{41}$ Dengan demikian jelaslah bahwa, bagi Paulus, salib merupakan hal yang sangat penting karena merupakan inti berita Injil. Selain itu, bagi Paulus salib juga merupakan titik peralihan bagi situasi manusia. ${ }^{42}$ Teologi salib merupakan inti dari solusi atas persoalan manusia. ${ }^{43}$ Pada bagian berikut akan dipaparkan signifikansi salib bagi kehidupan manusia dalam perspektif Teologi Paulus.

\section{Salib adalah Kekuatan Allah}

Di dalam teologi Paulus, salib dipandang sebagai kekuatan Allah (1 Korintus 1:17-18). Pandangan ini bertolak belakang dengan cara pandang masyarakat pada masa itu. Terlebih, yang tersalib adalah Yesus yang diyakini oleh Paulus sebagai Mesias. Ketika Paulus memberitakan Yesus yang tersalib, hal itu dianggap sebagai kebodohan. Bagi orang Yahudi di Korintus, sosok Mesias yang diharapkan bukanlah seorang yang mati tak

\footnotetext{
${ }^{40}$ Moris, 88-89

${ }^{41}$ Moris, 88-89

42 Tom Jacobs, Paulus, Hidup dan Karyanya, (Yogyakarta: Kanisius, 1983), 139.

${ }^{43}$ Jacobs, Paulus, Hidup dan Karyanya, 139.
} 
berdaya di atas kayu salib, melainkan sosok pembebas secara politis yang akan mengembalikan bangsa Israel pada zaman keemasan. Kematian sang juru selamat adalah sandungan bagi mereka. Sedangkan bagi orang-orang Yunani yang telah mahir dalam mengembangkan seni dan ilmu pengetahuan, berita salib tidak dapat memuaskan ras ingin tahu. Pengajaran tersebut bertolak belakang dengan pemikiran mereka. Mana mungkin sang juru selamat harus mati tanpa mampu menyelamatkan diri-Nya sendiri? Hal Ini adalah kebodohan. Namun demikian Paulus tidak malu memberitakan salib. Bahkan dia menjadikan berita salib sebagai inti berita Injil. ${ }^{44}$ Sehingga ketika sampai di Korintus, dia memutuskan untuk tidak mengetahui apa-apa selain Yesus Kristus yang tersalib (1 Korintus 2:2). Chamblin menegaskan bahwa salib terletak di pusat euangelion Paulus. ${ }^{45}$

Inti berita Injil ini diingatkan kembali oleh Paulus kepada jemaat di Korintus (I Korintus 15:1-4). Paulus mengingatkan bahwa melalui Injil tersebut jemat Korintus diselamatkan (1 Korintus 15:2). Selain mengingatkan tentang kekuatan Injil yang menyelamatkan, dia juga menjelaskan kembali tentang inti dari berita Injil yaitu karya Allah untuk menyelamatkan manusia melalui Yesus Kristus Anak-Nya yang telah mati, dikubur, dan bangkitkan pada hari yang ke tiga. ${ }^{46}$ Meskipun bagi mereka yang tidak percaya, salib merupakan kebodohan belaka., namun bagi Paulus, berita salib merupakan kekuatan Allah yang menyelamatkan setiap orang percaya pertama-tama orang Yahudi, tetapi juga orang Yunani (Roma 1:16).

\section{Salib adalah tempat pertukaran}

Paulus menunjukkan fakta rohani pada diri orang berdosa sebagai berikut: pertama, semua manusia telah berbuat dosa. ${ }^{47}$ Paulus menegaskan keadaan setiap manusia dengan mengutip tulisan pemazmur sebagai berikut:

"seperti ada tertulis: "Tidak ada yang benar, seorang pun tidak.

Tidak ada seorang pun yang berakal budi, tidak ada seorang pun

\footnotetext{
${ }^{44}$ Jacobs, Paulus, Hidup dan Karyanya, 139.

${ }^{45}$ J. Knox Chamblin, Paulus dan Diri: Ajaran Rasuli Bagi Keutuhan Pribadi, (Surabaya: PN. Momentum, 2006), 66

46 David Eko Setiawan, "Dampak Injil Bagi Transformasi Spirital dan Sosial", Jurnal BIA. Vol. 2, No.1, 2019; 86-87.

${ }^{47}$ David Eko Setiawan, "Kelahiran Baru Di Dalam Kristus Sebagai Titik Awal Pendidikan Karakter Unggul”, Evangelikal: Jurnal Teologi Injili dan Pembinaan Warga Jemaat. Vol. 3, No.2, 2019;159.
} 
yang mencari Allah. Semua orang telah menyeleweng, mereka semua tidak berguna, tidak ada yang berbuat baik, seorang pun tidak". ${ }^{48}$

Selanjutnya rasul Paulus tanpa ragu-ragu menyimpulkan bahwa semua orang telah berbuat dosa dan telah kehilangan kemuliaan Allah" ${ }^{49}$ Akibat dari keberdosaan tersebut maka manusia mendapatkan upahnya yaitu maut (Roma 3:23). Maut dalam teks tersebut berarti neraka, yaitu tempat dimana manusia mendapatkan penghukuman kekal akibat keberdosaanya. ${ }^{50}$ Namun demikian pasti ada sebagian dari orang bertanya, "Dari manakah kondisi keberdosaan semua manusia ini berasal?" Rasul Paulus menjelaskan imputasi dosa di dalam Roma 5:12. ${ }^{51}$ Akibat kejatuhan Adam maka dosa masuk ke dalam dunia oleh karena dia. Dan oleh dosa itu pula maka maut menjalar kepada kepada semua orang. Demikianlah kondisi keberdosaan manusia itu terjadi. Lalu bagimanakah proses keberdosaan manusia ini terjadi? Partisipasi semua manusia di dalam dosa Adam dapat digambarkan seperti contoh sebagaimana Lewi (meskipun belum dilahirkan) membayar perpuluhan kepada Melkisedek melalui Abraham di mana Lewi telah hadir sebelumnya di dalam Abraham (Ibrani 7:9-10), dengan cara yang sama, semua manusia telah secara keturunan hadir dalam Adam pada waktu dia berdosa dan karena itu semua manusia berperan serta dalam dosa itu. ${ }^{52}$

Rasul Paulus kemudian menunjukkan fakta rohani yang kedua yaitu bahwa keberdosaan manusia itu menjadikan segala usaha yang dilakukannya untuk melepaskan diri dari dosa adalah kesia-kesian belaka. Keberdosaan manusia telah membuatnya terpisah dari Allah sehingga kehidupan yang dijalani bukanlah kehidupan yang dikehendaki oleh Sang Penciptanya. ${ }^{53}$ Setiap usaha yang dilakukannya untuk terlepas dari kondisi tersebut sia-sia adanya. Keinginan untuk selamat dari penghukuman kekal tak dapat terpenuhi bila diusahakan dengan caranya sendiri. Karena pada dasarnya adalah pemberian Allah. Paulus menjelaskan hal itu di dalam surat

${ }^{48}$ Roma 3:10-12

${ }^{49}$ Roma 3:10-12

${ }^{50}$ Metthew Henry, Tafsir Metthew Henry: Surat Roma, 1 dan 2 Korintus, 154.

${ }^{51}$ Kata imputation berasal dari kata Latin imputare yang berarti memperhitungkan, mendakwakan pada seseorang dan berhubungan dengan masalah bagaiman dosa didakwakan pada setiap orang.

52 Paul Enns, The Moody Handbook, (Malang: Literatur SAAT, 2004), 387.

${ }^{53}$ Packer, 68 
Efesus 2:8-9 sebagai berikut, "Sebab karena kasih karunia kamu diselamatkan oleh iman; itu bukan hasil usahamu, tetapi pemberian Allah, Itu bukan hasil pekerjaanmu: jangan ada orang yang memegahkan diri”.

Kasih Karuni Allah tersebut diwujudkan melalui kematian anak-Nya yang tunggal disalib. Paulus memandang bahwa kematian Kristus disalib telah menggantikan hukuman orang-orang berdosa. Paulus mengatakan, "Dia yang tidak mengenal dosa telah dibuat-Nya menjadi dosa karena kita, supaya dalam Dia kita dibenarkan oleh Allah". ${ }^{54}$ Moris mengartikan ayat tersebut sebagai berikut,

"Arti ayat ini rupanya sebagai berikut: Kristus menggantikan orang-orang berdosa dan menanggung apa yang seharusnya mereka tanggung. Pada akhirnya kita harus mengakui adanya unsur misteri di dalamnya, namun rasanya cukup jelas fakta bahwa Kristus menanggung apa yang seharusnya ditanggung oleh orang-orang berdosa". .5

Paulus memandang salib sebagai tempat pertukaran (II Korintus 5:21). Henry menjelaskan pertukaran tersebut sebagai berikut,

"Kemurnian Sang Pengantara: Dia tidak mengenal dosa telah dibuat menjadi dosa. Maksud dan rancangan dari semuanya ini: supaya dalam Dia kita dibenarkan oleh Allah, dibenarkan dengan cuma-cuma oleh anugerah Allah melalui penebusan di dalam Kristus Yesus. Perhatikanlah. Sebagaimana Kristus, yang tidak mengenal dosa apapun dalam diri-Nya sendiri, telah dijadikan dosa untuk kita, demikian pula kita, yang tidak mempunyai kebenran apapun dalam diri kita sendiri, dibenarkan oleh Allah di dalam Dia.

Pendamian kita dengan Allah hanya melalui Yesus Kristus, dan oleh karena jasa-Nya". ${ }^{56}$

Berdasarkan penjelasan Henry di atas maka jelaslah bahwa di atas salib telah terjadi pertukaran antara Kristus Yesus dengan manusia berdosa. Melalui Dia pendamaian antara orang berdosa dengan Allah terjadi. Salib seharusnya menjadi tempat dimana setiap orang berdosa dihukum, namun karena anugerah-Nya mereka dibenarkan. Inilah Teologi Paulus tentang

${ }^{54}$ II Korintus 5:14

55 Moris, 89

${ }^{56}$ Metthew Henry, Tafsir Metthew Henry: Surat Roma, 1 dan 2 Korintus, (Surabaya: Penerbit Momentum, 2015), 891. 
salib yaitu merupakan tempat pertukaran hukuman atas orang berdosa yang ditimpakan kepada Yesus, agar mereka yang percaya tidak menerima hukuman melainkan diselamatkan oleh Allah.

\section{Salib merupakan jaminan kebebasan dari Kutuk}

Paulus secara tegas menyatakan bahwa melalui salib, Kristus telah menebus orang percaya dari kutuk hukum Taurat (Galatia 3:13). Di dalam ayat tersebut Paulus juga mengutip ayat dalam PL yaitu Ulangan 21:23, dimana kutuk yang dimaksud di dalam ayat tersebut adalah pelanggaran terhadap hukum Allah (Ulangan 27:26). ${ }^{57}$ Akibat pelanggaran tersebut, manusia menjadi terkutuk dan layak dihukum. Kondisi ini dijelaskan oleh Paulus dalam surat Efesus 2:1-3 sebagai kondisi yang hidup tetapi mati, durhaka dan dimurkai oleh Allah. Setiawan menjelakan hal tersebut sebagai berikut,

"Berdasarkan teks di atas, Paulus menunjukkan keadaan manusia berdosa yaitu: Pertama, hidup tetapi mati. Meskipun mereka secara jasmani hidup dan dapat melakukan sesuatu, namun pada dasarnya mati secara rohani karena dosa. Kedua, durhaka. Manusia berdosa hidup dalam segala macam kejahatan dan berprilaku jahat. Ketiga, dimurkai. Akibat dari keberdosaannya, mereka hidup dalam murka Allah. Ketiga keadaan tersebut membuat manusia berdosa mustahil untuk berubah dengan sendirinya. Mereka hanya patut dihukum oleh Allah". 58

Kondisi manusia berdosa tersebut di atas telah terjadi semenjak di dalam kandungan. Ini adalah kabar buruk yang harus didengar oleh setiap manusia. Packer menjelaskan hal ini sebagai berikut, "Kabar buruk tersebut adalah bahwa seluruh ras manusia, semenjak pembentukan janin dalam kandungan, sudah melawan Allah". ${ }^{59}$ Perlawanan manusia semenjak di dalam kandungan terhadap Allah merupakan kutuk yang harus dilepaskan.

Paulus memandang bahwa kelepasan terhadap kutuk di atas hanya dapat terjadi melalui salib. Teologi Paulus tentang salib sangatlah jelas,

\footnotetext{
${ }^{57}$ Henry, Tafsir Metthew Henry: Surat Roma, 1 dan 2 Korintus, 891

${ }^{58}$ David Eko Setiawan, "Kelahiran Baru Di Dalam Kristus Sebagai Titik Awal Pendidikan Karakter Unggul”, 159.

${ }^{59}$ J.I Packer, Melakukannya dengan Caraku: Apakah Kita Dilahirkan untuk Memberontak (Batam: Gospel Pers, 2002), 65
} 
bahwa melalui penumpahan darah Yesus Kristus, kekudusan Allah telah dipuaskan dan murka Allah telah dialihkan. ${ }^{60}$ Salib adalah jaminan bahwa kutuk tersebut telah disingkirkan. Hal ini selaras dengan penjelasan Barclay sebagai berikut, "Namun Firman Allah berkata pula, bahwa setiap orang yang tergantung di tiang gantungan terkutuk adanya (Ulangan 21:23). Dan itulah sebabnya Yesus sendiri menjadi yang terkutuk untuk membebaskan kita semua dari kutukan hukum Taurat itu". ${ }^{61}$ Bagi orang percaya kutuk sudah tidak berlaku lagi karena kematian Kristus di atas kayu salib telah menyingkirkannya secara efektif. ${ }^{62}$

\section{Salib Adalah tempat Pendamaian}

Bagi Paulus, tempat terbaik untuk meruntuhkan permusuhan antara Allah dengan manusia adalah salib. Di atas kayu salib, permusuhan itu berhenti. Menurut Roma 5:10 ketika manusia masih menjadi seteru Allah, Kristus mati demi pendamaian tersebut. ${ }^{63}$ Henry menjelaskan dampak pendamian berdasarkan Roma 5:10 sebagai berikut, "Dosa diampuni, oranng berdosa diterima sebagai orang benar, perselisihan didamaikan, permusuhan disingkirkan, kejahatan diakhiri, dan kebenaran yang kekal dibawa masuk". ${ }^{64}$ Selanjutnya, Paulus menyebut bahwa karya pendamaian itu terjadi oleh salib. ${ }^{65}$ Dan hasil dari pendamaian tersebut adalah terbukanya jalan masuk kepada Bapa dalam satu Roh (Efesus 2:18). Stott menjelaskan frasa jalan masuk pada ayat 18 sebagai berikut,

"Kata Yunani Prosagoge -jalan masuk atau akses-mengacu pada ruang tamu di istana, di ruang mana raja bersedia membahas suatu masalah dan menerima para bawahan yang diperkenalkan kepadanya. Tapi jalan masuk yang tersedia bagi kita adalah menuju hadirat Allah yang Bapa kita-rahmani dan pengampun, bukan raja atau penguasa lalim. Hal itu adalah mungkin karena di dalam Dia (Kristus) kita beroleh keberanian dan jalan masuk kepada Allah

${ }^{60}$ Paul Enns, The Moody Handbook, (Malang: Literatur SAAT, 2004), 132

${ }^{61}$ William Barclay, Pemahaman Alkitab Setiap Hari: Surat Galatia, (Jakarta: BPK Gunung Mulia, 2012), 43.

${ }^{62}$ Moris, 89-90

${ }^{63}$ Harun Hadiwijono, Iman Kristen (Jakarta: BPK Gunung Mulia, 1995), 346

${ }^{64}$ Henry, Tafsir Metthew Henry: Surat Roma 1 dan 2 Korintus, 121

${ }^{65}$ Henry, Tafsir Metthew Henry: Surat Roma 1 dan 2 Korintus, 347 
dengan penuh kepercayaan...Jadi karya agung Kristus selanjutnya ialah tersedianya jalan masuk kepada Allah Bapa melalui diri-Nya sendiri, sehingga Yahudi dan non-Yahudi dalam satu Roh beroleh keberanian mendekati Allah". 66

Berdasarkan penjelasan Stott di atas tampak bahwa Paulus sedang menunjukkan dampak ajaib dari karya pendamaian Allah di dalam Kristus, yaitu menghancurkan tembok yang memisahkan antara Allah dengan manusia sehingga terbangunlah relasi yang intim diantara mereka.

Dalam teologi Paulus, peristiwa salib merupakan momentum yang sangat penting bagi Allah dan manusia. Sebab melalui peristiwa tersebut pendamian antara Allah dan manusia terjadi. Hal ini selaras dengan komentar Niftrik atas Roma 5:9 berikut,

"Kristus benar-benar telah mengorbankan diri-Nya sebagai ganti kita. Dia sendirilah Korban itu sebagai ganti kita. Maka di dalam Kristus, kita kembali menjadi milik Allah. Allah sendiri telah memulihkan hubungan yang seharusnya antara Dia dengan manusia". ${ }^{67}$

Dari penjelaan Niftrik di atas tampak jelas bahwa di atas salib Yesus menjadi korban pengganti. Melalui pengorbanan-Nya yang sempurna itu orang berdosa kembali didamaikan dengan Allah bahkan kembali menjadi milik Allah.

Selanjutnya Gutrie menjelaskan bahwa penggunaan kata kerja katalasso (memperdamaikan) dan kata benda katallage (pendamian) oleh Paulus dalam Roma 5:8-11 menunjukkan dua ciri penting sehubungan dengan karya Kristus dalam pendamian, yaitu pertama, pendamaian dikontraskan dengan perseteruan, dan kedua, pendamian dianggap sebagai realitas yang benar-benar dikerjakan oleh kematian Kristus. ${ }^{68}$ Gutrie memaparkan ciri pertama sebagai berikut,

"Kita pertama-tama mencatat dalam nats ini pendamaian dikontraskan dengan perseteruan, perseteruan yang dimaksud

\footnotetext{
${ }^{66}$ John R.W. Stott, Seri Pemahaman dan Penerapan Amanat Alkitab Masa Kini: Efesus, (Jakarta: Yayasan Komunikasi Bina Kasih/OMF, 2003), 99

${ }^{67}$ G.C van Niftrik (et.all), Dogmatika Masa kini(Jakarta: BPK Gunung Mulia, 1995), 260

${ }^{68}$ Donald Gutrie, Teologi Perjanjian Baru II, (Jakarta: BPK Gunung Mulia, 2008), 
bukan hanya perseteruan manusia terhadap Allah, tetapi mencakup juga perseteruan tentang murka Allah terhadap dosa. Hal ini didukung oleh adanya pernyataan-pernyataan tentang murka Allah dalam Roma $1: 18 ; 2: 5,8 ; 3: 5 ; 4: 15 .$. Ini berarti bahwa karya pendamaian Kristus adalah mutlak penting. Tiada orang yang dapat menghadapi murka itu kecuali jika Allah sendiri campur tangan". 69

Ciri kedua sehubungan dengan karya Kristus dalam pendamian menurut Roma 5:8-11 dijelaskan oleh Gutrie sebagai berikut,

"Ciri kedua dari nats ini ialah pendamian dianggap sebagai suatu realitas yang benar-benar dikerjakan oleh kematian Kristus. Itu bukan sekedar perubahan sikap dari orang berdosa. Seandainya artinya demikian, maka kematian Kristus tidak diperlukan. Sama sekali tidak ada dikatakan bahwa dalam PB kematian Kristus demikian sangat mengesankan musuh-musuh-Nya sehingga mereka menghilangkan rasa perseteruan mereka. Menurut ayat 10 'kita diperdamaikan', artinya pendamian itu sudah dikerjakan, entah manusia menerimanya atau tidak, namun yang pasti Allah sendiri didamaikan dengan manusia melalui kematian Kristus. Tindakan mendamaikan ini sudah selesai (kata kerja dalam bentuk aoris)" ${ }^{70}$

Berdasarkan penjelasan Gutrie di atas tampak bahwa Paulus memandang salib sebagai tempat yang tepat untuk mendamaikan perseteruan Allah dengan manusia akibat dosa. Di atas salib pendamian itu telah terjadi bagi seluruh manusia.

\section{Simpulan}

Signifikansi Salib di dalam bagi kehidupan manusia dalam teologi Paulus sangat jelas. Adapun salib di dalam teologi Paulus adalah sebagai berikut: Pertama, Salib adalah Kekuatan Allah yang menyelamatkan setiap orang percaya pertama-tama orang Yahudi, tetapi juga orang Yunani (1 Korintus 1:17-18; Roma 1:16). Kedua, Salib adalah tempat pertukaran, dimana hukuman atas manusia berdosa ditimpakan kepada Yesus, agar mereka yang percaya tidak menerima hukuman melainkan dibenarkan oleh Allah (II Korintus 5:21). Ketiga, Salib merupakan jaminan kebebasan dari

\footnotetext{
${ }^{69}$ Gutrie, 111.

${ }^{70}$ Gutrie, 111.
} 
kutuk (Galatia 3:13). Setiap orang yang percaya kepada-Nya akan dibebaskan dari kutuk yaitu perlawana terhadap Allah dan murka-Nya. Keempat, Salib adalah tempat Pendamian (Roma 5:10; Efesus 2:18). Mereka yang percaya didamaikan dengan Allah melalui Kristus.

\section{Daftar Pustaka}

\section{Alkitab}

Allen, Roland, Missionary Method: St. Pauls or Ours? Library of Historic Theology. London: Robert Scott Roxburghe, 1912

Barclay, William, Pemahaman Alkitab Setiap Hari: Surat Galatia, Jakarta, BPK Gunung Mulia, 2012.

Bock, Darrell L , A Biblical Theology of The New Tastement. Malang: Penerbit Gandum Mas, 2011.

Drane, John, Memahami Perjanjian baru. Jakarta: BPK Gunung Mulia, 2005.

Enns, Paul, The Moody Hand Book Of Theology. Malang: Literatur SAAT, 2004.

Fatoohy, Louay, The Mystery of the Crucifixion: The Attempt to Kill Jesus in the Qur'an, New Testament and Historical Sources. Birmingham: Luna Plena Publishing, 2008.

Gutrie Donald, Teologi Perjanjian Baru II, Jakarta, BPK Gunung Mulia, 2008.

Hadiwijono, Harun, Iman Kristen. Jakarta: BPK Gunung Mulia, 1995.

Marsunu, YM Seto, Paulus Sukacita Rasul Kristus. Yogyakarta: Penerbit Kanisius, 2012.

Henry, Metthew, Tafsir Metthew Henry: Surat Roma, 1 dan 2 Korintus, Surabaya, Penerbit Momentum, 2015.

Heriyanto, "Thematic Analysis sebagai Metode Menganalisa Data untuk Penelitian Kualitatif'. ANUVA: Jurnal Kajian Budaya, Perpustakaan dan Informasi, Vol. 2, No. 3, 2018.

Kapojos, Shintia Maria dan Hengki Wijaya, "Konsep Bermegah (Boasting) dalam Surat Roma dan Implikasinya bagi Gereja Masa Kini”, Fidei: Jurnal Teologi Sistematika dan Praktika, Vol. 2, No. 1, 2019.

Moris, Leon, Teologi Perjanjian Baru. Malang: Penerbit Gandum Mas, 1996. 
Nggadas, Deky Hidnas Yan dalam Tinjauan kritis terhadap buku Louay Fatoohy "The Mystery of the Crucifixion". Diakses dari www.academia.edu. 15 Februari 2019. Pukul 23.30 WIB.

Niftrik, van G.C. Et.all, Dogmatika Masa kini. Jakarta: BPK Gunung Mulia, 1995.

Packer, JJ., Melakukannya dengan Caraku: Apakah Kita Dilahirkan untuk Memberontak.Batam: Gospel Pers, 2002.

Ronda, Daniel, "Kepemimpinan Kristen Di Era Disrupsi Teknologi." Evangelikal: Jurnal Teologi Injili dan Pembinaan Warga Jemaat, Vol. 3, No. 2, 2019.

Schnabel, Eckhard J., Rasul Paulus Sang Misionaris: Perjalanan, Startegi, dan Metode Misi Rasul Paulus. Yogyakarta: Yayasan Andi, 2008.

Setiawan, David Eko, "Kelahiran Baru Di Dalam Kristus Sebagai Titik Awal Pendidikan Karakter Unggul”, Evangelikal: Jurnal Teologi Injili dan Pembinaan Warga Jemaat. Vol. 3, No.2, 2019.

Sosial”, Jurnal BIA. Vol. 2, No.1, 2019.

Yogyakarta: Diandra, 2017.

Stott, John R.W, Seri Pemahaman dan Penerapan Amanat Alkitab Masa Kini: Efesus, Jakarta, Yayasan Komunikasi Bina Kasih/OMF, 2003.

Tindball, Derek J., Teologi Penggembalaan. Malang: Penerbit Gandum Mas. 1995. 